Alipbayev A., Byuzheyeva B.

The struggle for leadership in the Asia-pacific region: China and Japan

Әліпбаев А.Р., Бөжеева Б.З.

Азия-Тынық мұхит

аймағындағы көшбасшылық үшін күрес: Қытай және Жапония

А^ипбаев А.Р., Бюжеева Б.3.

Борьба за мидерство в Азиатско-Тихоокеанском регионе: Китай и Япония
In article the present condition and prospects of the Chinese-Japanese global cooperation and rivarly in their combination are considered. The Chinese approaches to development of the political and economic relations with Japan both the Japanese vision of an eminence of China and possible reaction of Japan to this eminence are estimated. The key role of China and Japan in evolution of a general situation on space of East Asia and, especially, in real development of East Asian integration is analyzed. In general, it is represented that promotion on two vectors - "An ASEAN - China» and "an ASEAN - Japan» will become the real direction of deepening of integration processes in East Asia. Integration of China and Japan on such burning issues as a sinuation on the Korean peninsula, influence of extraregional players is considered.

Key words: China, Japan, ASEAN, state, policy, cooperation, integration, economy.

Мақаяада қазіргі кезеңдегі жапон-қытай жаһандық ынтымақтастығы мен бәсекелестігінің жағдайы мен келешегі нақты екеуінің үндестігінде қарастырылады. Жапониямен саяси-экономикалық қатынастарының дамуына қатысты Қытайдың ыңғайы және Қытайдың өрлей түсуіне жапондық көзқарас пен осы өрмеуге байланысты Жапония тарапынан шығуы мүмкін әрекеттері сараланады. Қытай мен Жапонияның Шығыс Азия кеңістігіндегі жалпы жағдайдың эволюциясына және әсіресе, шығысазиялық интеграцияның нақты дамуындағы негізгі рөлі сарапталады. Жалпы, «АСЕАН - Қытай» және «АСЕАН - Жапония» екі тармағында алға жылжуы Шығыс Азиядағы интеграциялық үдерістерінің тереңдей түсуінің нақты бағыты болары айқын. Корей түбегіндегі ахуал сияқты өзекті мәселелерге қатысты Қытай мен Жапония арасындағы өзара іс-қимылдар, аймақтан тыс жатқан елдердің ықпалы қарастырылады.

Түйін сөздер: Қытай, Жапония, АСЕАН, мемлекет, саясат, ынтымақтастық, интеграция, экономика.

В статье рассматриваются нынешнее состояние и перспективы китайско-японского глобального сотрудничества и соперничества именно в их сочетании. Оцениваются китайские подходы к развитию политических и экономических отношений с Японией и японское видение возвышения Китая и возможная реакция Японии на это возвышение. Анализируется ключевая роль Китая и Японии в эво^юции общей ситуации на пространстве Восточной Азии, и особенно в реальном развитии восточноазиатской интеграции. В целом, преАставляется, что продвижение по векторам «АСЕАН - Китай» и «АСЕАН - Япония» станет реальным направлением углубления интеграционных процессов в Восточной Азии. Рассматривается взаимодействие Китая и Японии по таким острым проблемам, как ситуация на Корейском полуострове, влияние внерегиональных игроков.

КАючевые слова: Китай, Япония, АСЕАН, государство, политика, сотрудничество, интеграция, экономика. 
*Alipbayev A., Byuzheyeva B.

Al-Farabi Kazakh National University, Kazakhstan, Almaty

*E-mail: Alipbayev19@gmail.com

\section{THE STRUGGLE FOR LEADERSHIP IN THE ASIA-PACIFIC REGION: CHINA AND JAPAN}

\section{Introduction}

Asia-Pacific region represents one of the largest centres in the world of financial resources, international trade, technology, modern production. In the Pacific region are intertwined interests of different countries, playing a major role in today's international political and economic relations. The leading countries of the world, Japan, China, US, Russia are trying to find their key positions in the region.

\section{Rivalry and interaction of Japan and China}

Competition and cooperation of Japan and China exerts its influence on the world of economy and politics. On the one hand, China and Japan are the key resource for economic growth for each other, and the increasing economic dependence on each other pushing them to look for other solutions to the mutually beneficial co-development in East Asia. On the other - exacerbated the struggle for a more influential position in the international arena, for the lead in the space of states of East Asia, with the output states to new sources of energy. One group of interests - economic benefits, «non-traditional» security threats - strengthens the component «cooperation» in relations between Beijing and Tokyo, it brings them objectively. Then the other - the competition in the economy, energy and politics - the country pushes apart reinforcing component «rivalry.»

The root causes of the rise of conflicts of Sino-Japanese relations are rooted in the new international phenomenon - temporary political parallelism elevation and Japan, and China on the basis of their global economic role, recognized by the world community. Based on its economic successes and opportunities, Beijing and Tokyo - in parallel and at the same time - look for ways to increase their own role in global and regional politics, seeking to have the right and the opportunity to influence the formation of a new architecture of international security and co-development of the World.

Both countries have long sought to become the leading regional power. Since the 80 s of last century, Japan became the first country to initiate the establishment of an East Asian community, and Japanese economists have put forward the idea of «a flock of flying 
geese» economic cooperation in East Asia, where Japan acted as a «leader goose», followed by four «Asian dragon», and behind them - the developing countries such as Malaysia and China. But in the beginning of the XXI century, when the Japanese economy was in recession and the global and regional situation has changed dramatically, the concept of «goose flock» has remained only on paper. In 2002, Prime Minister of Japan, Junichiro. Koizumi called for an «East Asian bloc» in order to regain a leading role in this association, but this idea has not been implemented.

However, Japan still wants to gain control over East Asia. On November 30, 2004 during the ASE$\mathrm{AN}+3$ summit, Koizumi made a proposal to make Japan the chairman of the East Asia Summit in 2005, to the time to get the leading role in this format. The proposal did not meet with unanimous approval by the ASEAN countries [1].

During the reign of the new Chinese leadership under Hu Jintao (since 2002-2003.) there were significant changes in the foreign and security policy of China strategy and the means to ensure it. At the heart of change - both objective and subjective factors. The former include the need to respond to the globalization of the Chinese economy. To the second - changing the mentality of the Chinese political elite. In late 2005, at the UN summit in Hu's speech was formulated a new strategy of Chinese diplomacy to «build a harmonious world», under the supervision means «to achieve political balance:

(1) between their own country's development and the responsibility of the international community,

(2) between the economic, political and security interests in the relations between the great powers,

(3) between the holding of an international order reforms and ensure « [2].

Despite the improvement in relations between ASEAN and China in the new century, China is still perceived in the ASEAN with a certain anxiety and discomfort. Hence - Tokyo regional leaders perceived as a balancer to China, which allows ASEAN, on the one hand, to contain China, on the other - to play on the rivalry between Beijing and Tokyo for leadership in ASEAN relations. ASEAN capitals believe where China, Japan, and there will be, and with superior resources. Competition in the triangle of China - Japan - ASEAN ASEAN is the vector - China for Japanese investment. In general, it appears that the promotion of two vectors - the «ASEAN - China» and «ASEAN - Japan» will be a real trend of deepening the integration process in East Asia.

Economic growth and the strengthening of China's political influence in the world over the past three decades have created a real competition of Japan in East Asia. Now, the key players in the two countries have become regional space in China and Japan. Both states are both partners and competitors. From their interaction depends critically on the progress of East Asian economic integration.

In East Asia, exacerbated by the Sino-Japanese rivalry for economic and political influence in the region. In the area of trade, China steadily increasing imports from East Asia, which accounts for more than half of China's imports. Imported products are mainly for processing and assembly of finished products to its further expansion into the markets of Western countries. Trade is growing and China's purchases from neighbouring countries for the region to extinguish dissatisfaction with recent repression of their products in the US and Europe Chinese goods. However, in recent years significantly increases the investment attractiveness of China for Asia, compared with Japan. In East Asian countries account for two-thirds of the volume of incoming foreign investment in China, and only 5\% - in Japan. Exports of Japanese investments in the countries of the region and more than modest and does not exceed $20 \%$ of the total export of capital from Japan [3].

To date, Japan and China - the two major powers in the western Pacific Ocean, but the United States does not belong geographically to the region to play a very important role here because of its strong economic and military-political presence. Folding the balance of forces in the triangle of Washington Beijing - Tokyo and in the future, perhaps the most important for the evolution of the situation in East Asia and, more broadly, in the Asia-Pacific region. Among the external factors that influence the state and development of Sino-Japanese relations, the US, of course, remains one of the most obvious and important.

Also, China and Japan are playing a leading role in the Korean peninsula. Sino-South Korean relations is based on a fundamental basis: the commitment to the values of democracy and market economy, the involvement of both countries in the political-military alliance with the US, mutual desire to work together to ensure security on the Korean Peninsula and in Northeast Asia. However, the value of the Japanese-Korean relations should be evaluated not only through the prism of the state 
of the bilateral dialogue. From the point of view of Tokyo, emphasizes the director of East Asian Studies Center at the Institute of International Relations (Monterey, CA) C Akaha, the Korean Peninsula remains largely "gate openers Japan's path to Asia» and Korean policies gives an indication of the content of the Japanese foreign policy in general [4]. In this context, the relationship with Tokyo to Beijing's policy on the Korean peninsula allows you to better present the position of Japan regarding the growing Chinese influence on the situation in the world, primarily in the Northeast Asia. China is also suited to the relation with the two Korean states as an important element unified foreign policy concept, built on the basis of coordination of the political, economic, military and humanitarian. At the same time the Korean direction of Chinese foreign policy manifested accents, reflecting the development of relations with key partners, including Japan [5].

In the Document of the JapaneseDefense Agency, «Guidelines for the National Defense Program -2005 » are reflected the probable military conflicts, such as the natural resources in the disputed area of the East China Sea territorial dispute over the Senkaku Islands, the support of the United States by Japan in its conflict with the of China over Taiwan , and among these problems territorial dispute over the Diaoyu islands (Senkaku).

The most difficult issue for modern China is to assess Japan's commitment to the attainment of a high international weight (including getting the UN Security Council permanent member status), and the lifting of restrictions on the use of the armed forces, imposed on Japan to its post-war constitution.

One of the factors determining the prospects for cooperation between China and Japan in the context of global and regional globalization, is the stability and predictability of high political models in both countries. Also close trade and economic ties have formed a natural economic interdependence between the two countries. China and Japan use it for mutual benefit and in order to ensure their own economic security.

Two great neighbor eager to develop relations in the direction of the strategic partnership. However, they present and continue to present a number of potential challenges. The root causes of this is hidden rivalry in the struggle for the acquisition of power in the Asia-Pacific region. At the same time, nationalism and a sense of national dignity will always put the leadership of the two countries to have to make a clear choice, in order to prevent the situation worsening.

\section{Conclusion}

Our conclusions regarding the economic positions of China and Japan in East Asia reduced to the fact that it takes a significant niche in the field of trade in Japan, but in the field of investment cooperation place and role of China in the region, much stronger. After its successful role in overcoming the consequences of the Asian financial crisis (1997 -. 1998) China is actively lobbying for free trade agreements with ASEAN and the individual countries of the region. Beijing successfully demonstrated in front of the East Asian countries, its benefits compared with Japan: a giant, open-air market is quite capable of absorbing both goods and investments, and to deliver a competitive and labor-intensivetehnikoemkuyu products and to invest in neighboring countries. As a result, China tightens regional trade and investment flows and successfully directs them to Western markets, including Japan.

Japan forced China to catch up by offering their draft agreements with ASEAN and the Republic of Korea. The only way for Japan in this regard is to maintain a high-technology and high-tech level of its economy and foreign economic relations, including the expansion of direct exports to the western markets and the opening of the domestic market for the import of goods, services and capital. And on this basis - the implementation of the idea of «ASEAN + 3 (Japan, China, South Korea),» as the foundation of East Asian integration instead forming dominance at the Chinese format «ASEAN plus China».

In general, the nature of the Sino-Japanese relations in the trade and economic sphere, suggests that they have good prospects for further development. This is facilitated by a factor of geographical proximity, long close historical and cultural ties, a reliable political framework of relations. There remains yet and a certain complementarity of the two economies: advanced scientific and technical basis, management experience of Japan naturally combined with the availability of natural resources and surplus labour force in China.

Changes to the prevalence of «Requirements for integration motivation» of «the need for domination,» «cooperative thinking» over the «alarmist» does not come automatically the next generation of leaders for change. They will require a wide-ranging dialogue between the Chinese and Japanese elites, between intellectuals, youth, between the «ordinary people». 


\section{Литература}

1 Современный Китай в системе международных отношений / отв. ред. Д.В. Буяров. - Благовещенск: «БГПУ», 2013. - Стр. 431-433.

2 Михеев В.В. Китай-Япония: конкуренция за лидерство [China-Japan: Competition for Leadership]. - M.: РАН ИМЭИМО, 2011. - С.104.

3 Потапов М. Экономическое соперничество и сотрудничество Китая и Японии в Восточной Азии. - М.: РАН ИМЭИМО, 2007. - С.25-31.

4 Akaha Ts. Japan's Multilevel Approach Toward the Korean Peninsula after the Cold War // Korea at the Center. Dynamics of Regionalism in Northeast Asia / Ed. By Charles K. Armstrong, Gilbert Rozman, Samuel S. Kim, Stephen Kotkin. - New York London, 2006. - P. 184.

5 Федоровский А. Китай и Япония на Корейском полуострове. - М.: РАН ИМЭИМО, 2014. - С. 88-94.

\section{References}

1 Modern China in the international system. Ed. ed. Buyarov D.V. - Blagoveshensk: «BGPU», 2013. - P. 431-433.

2 Mikheev V.V. Kitay-Yaponiya: konkurencia za liderstvo [China-Japan: Competition for Leadership]. - M.: RAS IMEIMO, 2011. -P.104.

3 Potapov M. Economic rivalry and cooperation between China and Japan in East Asia. - M.: RAS IMEIMO, 2007. - P.25-31.

4 Akaha Ts. Japan's Multilevel Approach Toward the Korean Peninsula after the Cold War // Korea at the Center. Dynamics of Regionalism in Northeast Asia / Ed. By Charles K. Armstrong, Gilbert Rozman, Samuel S. Kim, Stephen Kotkin. - New York. London, 2006. - P. 184.

5 Fedorovskii A. China and Japan on the Korean Peninsula. - M.: RAS IMEIMO, 2014. - P. 88-94. 
Центральная Азия - новый Аинамичный субригион всей Евразии и мира. Казахстан и другие государства, находящиеся зАесь Аоказали свою способность к суверенному, Аостойному, развитию.

Президент Республики Казахстан Нурсултан Назарбаев 